\title{
Ekklesiologie en Etiek: Die werk van Etienne de Villiers in die lig van die ekumeniese diskussie oor ekklesiologie en etiek
}

\author{
Author: \\ Conrad Wethmar ${ }^{1}$ \\ Affiliation: \\ ${ }^{1}$ Department of Dogmatics \\ and Christian Ethics, \\ University of Pretoria, \\ South Africa \\ Correspondence to: \\ Conrad Wethmar \\ Email: \\ conrad.wethmar@gmail.com

\section{Postal address:} \\ Private Bag X20, Hatfield, \\ Pretoria 0028, South Africa \\ Dates: \\ Received: 30 July 2012 \\ Accepted: 19 Sept. 2012 \\ Published: 06 Dec. 2012 \\ How to cite this article: \\ Wethmar, C., 2012, \\ 'Ekklesiologie en Etiek: Die \\ werk van Etienne de Villiers \\ in die lig van die ekumeniese \\ diskussie oor ekklesiologie \\ en etiek', Verbum et Ecclesia \\ 33(2), Art. \#772, 5 pages. \\ http://dx.doi.org/10.4102/ \\ ve.v33i2.772
}

C 2012. The Authors. Licensee: AOSIS OpenJournals. This work is licensed under the Creative Commons Attribution License.
Ecclesiology and Ethics: Etienne de Villiers' work in the light of ecumenical discussions on ecclesiology and ethics. In honouring Etienne de Villiers, this article discusses the latter's contribution to a deepening of the notions of church and ethics, as well as the mutual relationship between these notions in the South African context. De Villiers' work in this regard is compared with that which has been done by the World Council of Churches (WCC). The article therefore highlights the manner in which De Villiers, in line with the WCC, analysed the moral deformation, but also the transformation and formation in which especially the Dutch Reformed Church was involved in in South Africa since the middle of the 20th century. Although De Villiers mainly works in the field of Christian ethics, it is clear that the latent ecclesiological views to which his ethical contributions are related, would also, to a considerable extent, be in line with those that have been and are being developed by the WCC.

\section{Inleiding}

Maurice Wiles (2001) het enkele jare gelede beklemtoon dat vriendskap nie net vir die persoonlike sfeer belangrik is nie, maar dat dit ook akademies vrugbaar kan wees toe hy een van sy laaste boeke gepubliseer het met die titel $A$ shared search. Doing theology in conversation with one's friends. Hoe belangrik vriendskap vir die teologie kan wees, kan maklik aan die hand van enkele verwysings na klassieke voorbeelde uit die verlede bevestig word. Die vriendskap van Gregorius van Nazianzus met Basilius van Caesarea sou ' $n$ voorbeeld kon wees. 'n Voorbeeld nader aan ons tyd is dié van Karl Barth met Eduard Thurneysen.

Gelukkig is teologiese vriendskappe egter nie beperk tot klassieke gestaltes uit die geskiedenis nie. Almal van ons kan getuig dat vriendskap 'n veilige oord bied waarin onryp en voorlopige gedagtes tot groter helderheid gebring of van onbesonnenheid bewaar kan word. Ek is bevoorreg om al vir 47 jaar so 'n vriendskap met Etienne de Villiers te deel - 'n vriendskap wat nie net op 'n persoonlike vlak nie, maar ook op 'n akademiese vlak vir my besonder baie beteken.

Die beste manier om uitdrukking te gee aan 'n akademiese vriendskap, is om met die werk van die betrokke persoon in gesprek te tree. Die tema aan die hand waarvan ek hierdie artikel doen, is 'Ekklesiologie en Etiek. Die werk van Etienne de Villiers in die lig van die ekumeniese diskussie oor ekklesiologie etiek'.

\section{Kerk en morele deformasie}

Wanneer 'n mens De Villiers se publikasies bestudeer, is dit opvallend hoe dikwels hy etiese temas behandel met die oog op die verantwoordelikheid wat die kerk, spesifiek die Nederduits Gereformeerde (NG) Kerk, in die betrokke verband het. Titels soos die volgende kom voor: 'Die NG Kerk en die nuwe situasie in die samelewing', 'Die NG Kerk en die oorgang na 'n nuwe SuidAfrika', 'Die morele genesing van die Suid-Afrikaanse samelewing: die bydrae van die Afrikaanse kerke' en 'Kan die NG Kerk nog 'n konstruktiewe rol in die Suid-Afrikaanse samelewing speel?'. De Villiers se werk kan in hierdie opsig byna in etiese perspektief as kontemporêre Suid-Afrikaanse kerkgeskiedenis gelees word. Hierdie werk kan oorsigtelik in herinnering geroep word deur van die begrip morele formasie, wat in die meer onlangse ekumeniese diskussie oor die verhouding tussen ekklesiologie en etiek as rigtinggewend na vore getree het, as indelingsbeginsel gebruik te maak. (Forrester 1997:76-95). 'n Mens sou dan Etienne de Villiers se bydrae ten opsigte van die kerk se rol in die hedendaagse moraliteitsvorming aan die hand van drie gesigspunte kon bespreek, naamlik, (1) kerk en morele deformasie, (2) kerk en morele transformasie en (3) kerk en morele formasie.

Met hierdie benadering is ook reeds ' $n$ aanduiding gegee van die wyse waarop die betekenis en belang van De Villiers se werk in die lig gestel kan word. 'n Mens kan sy werk vergelyk met die wyse waarop die verhouding tussen ekklesiologie en etiek in die gestalte en werk van 
die Wêreldraad van Kerke neerslag gevind het. Die bepaling van die verhouding tussen ekklesiologie en etiek is nie net ' $n$ toevallige tema in die Wêreldraad se werk nie. 'n Mens sou selfs kon sê dat die Wêreldraad sy ontstaan en bestaan te danke het aan die noodsaak om aan die verband tussen ekklesiologie en etiek, soos dit onderskeidelik in die Faith and Order en Life and Work tradisies behartig word, uitdrukking te gee.

Om De Villiers se werk met dié van die Wêreldraad in terme van morele formasie te vergelyk, is voor die handliggend omdat die eerste gesigspunt, waaronder die verhouding tussen ekklesiologie en etiek in sy werk ter sprake kom, die deformasie is wat vanaf die 1960's in ekumeniese kringe gekonstateer is ten opsigte van die NG Kerk se morele impak op die Suid-Afrikaanse samelewing. Gedurende 1985 het De Villiers, naamlik as Von Humboldt-stipendiaat, 'n uitvoerige navorsingsprojek gewy aan die kritiek uit die ekumene op die NG Kerk se betrokkenheid by apartheid (De Villiers 1986, 1989). Hy het in hierdie verband veral op die volgende gesigspunte gewys.

Eerstens word daar gekritiseer dat die NG Kerk hom te veel met die belange van een bepaalde volk vereenselwig en sodoende kerkwees verstaan as die godsdienstige aspek van ' $n$ bepaalde groep. Dit dien dan as motivering om die belange van dié betrokke groep ten koste van die van ander groepe te verskans en te bevorder. Dit lei nie net daartoe dat die Bybelse gebod van geregtigheid in die gedrang kom nie, maar ook dat die koinonia of gemeenskap wat alle Christene kragtens hulle verbondenheid aan Christus met mekaar het, nie tot sy reg kom nie (De Villiers 1989:157-160).

Tweedens word daar uit die Wêreldraad-geledere daarop gewys dat daar 'n moreel deformatiewe invloed van die NG Kerk uitgaan omdat hierdie kerk sy profetiese roeping versaak deur te weier om fundamentele kritiek teen 'n onaanvaarbare politieke bestel te lewer. Met hierdie deformatiewe ontwikkeling hang saam dat gebrekkige solidariteit betoon word met slagoffers van apartheid en dat onverdraagsaamheid voorkom teen diegene uit eie geledere wat krities staan teenoor hierdie beleid (De Villiers 1986:155).

'n Derde gesigspunt is die feit dat 'n verabsolutering van rasgeskeidenheid daartoe gelei het dat die sigbare uitlewing van die eenheid van die kerk benadeel is. Hierdie gegewe vind uitdrukking in 'n streng beleid van afsonderlike kerke vir afsonderlike bevolkingsgroepe, 'n gebrekkige gemeenskapsbelewing tussen sogenaamde moeder- en dogterkerke, asook 'n afweer van ekumeniese gemeenskapsverhoudinge (De Villiers 1986:163).

Daar word verder beklemtoon dat die bogenoemde sake met 'n onvoldoende ekklesiologie saamhang. Die swakheid van hierdie ekklesiologie kan toegeskryf word aan die invloed van pietisme, wat die indiwidu ten koste van die gemeenskap beklemtoon, asook die invloed van die liberalisme, wat die kerk sien as die vereniging van gelykgesindes wat uit eie vrye wil bymekaarkom (De Villiers 1986:163).
Die kritiek wat vanuit die ekumene op die NG Kerk se betrokkenheid by apartheid gelewer is, soos deur De Villiers ontleed, het nie uit die lug geval nie. Om hierdie kritiek te verstaan en om te verstaan hoe kerklike morele deformasie deur transformasie en oriëntasie vervang kan word, is dit belangrik om die voorveronderstellinge, en met name die ekklesiologie, waarop die kritiek berus het, na te gaan.

Die feit dat De Villiers as etikus dit nie nodig geag het om 'n uitvoerige leerstellige ekklesiologie te ontwikkel nie, is 'n verdere rede waarom dit belangrik is om die voorveronderstellinge na te gaan. Van die begin van sy teologiese loopbaan af was hy meer geïnteresseerd in die sosiaal-etiese implikasies van teologiese kwessies as in die abstrakte dogmatiese kant daarvan. Vandaar dat hy destyds eerder by Kuitert as by Berkouwer gepromoveer het. Waar De Villiers dus in sy ontleding van die kerklike situasie in Suid-Afrika in 'n groot mate by die etiese oortuiginge aansluit wat in die breë ekumeniese beweging ontwikkel het, maar self nie 'n omvattende ekklesiologie uitgewerk het nie, sou 'n mens kon aanneem dat die grondlyne van sy latente ekklesiologie eweneens ooreenstemming met die basiese ekklesiologiese gedagtegange, waaroor daar 'n redelike mate van konsensus in die instansies van die Wêreldraad van Kerke tot stand gekom het, sal vertoon.

Om insig te kry in hoe 'n mate De Villiers se etiese opvattinge ingebed is in 'n ekklesiologie wat van huis uit wel Gereformeerd is, maar tog duidelik ook die invloed van ontwikkelinge in die wyer ekumeniese wêreld ondergaan het, is dit nodig om na te gaan hoe die ekklesiologie in die Wêreldraad van Kerke daar uitsien.

\section{Ekklesiologie van die Wêreldraad van Kerke}

Dit is verrassend om vas te stel dat die Wêreldraad vir die eerste 50 jaar van sy bestaan nie die antwoord op hierdie vraag kon of wou gee nie. Die rede daarvoor is dat die vraag na wat die aard en doel van die kerk is, juis 'n vraag is waaroor daar onenigheid tussen kerke bestaan. Vermyding van hierdie vraag was dus 'n voorwaarde vir die suksesvolle samewerking tussen die verskillende kerklike tradisies. Hierdie oortuiging was die basiese strekking van ' $n$ beleidsdokument wat die Sentrale Komitee van die Wêreldraad van Kerke in 1950 alreeds by 'n vergadering in Toronto aanvaar het. Alhoewel hierdie dokument, wat as die Torontoverklaring bekend geword het, nie deel van die konstitusie van die Wêreldraad is nie, het dit oor die jare heen byna kanonieke status gekry en 'n rigtinggewende rol gespeel in die wyse waarop die ekklesiologie in die Wêreldraadkonteks hanteer is (Wethmar 2010:509).

Dit is egter belangrik om te onthou dat die Torontoverklaring uit twee dele bestaan het. Die eerste deel bied die ekklesiologiese neutraliteitsverklaring, waarna pas verwys is, terwyl die tweede deel 'n aanmoediging aan die lidkerke bevat om die veilige ruimte van ekklesiologiese neutraliteit te gebruik om samewerking en wedersydse ondersteuning 
te soek. Oor die jare heen het hierdie aanmoediging daartoe gelei dat begrip en vertroue op verskillende maniere tussen kerke ontwikkel het, wat die verwagtinge wat in die 1950's gekoester is ver oortref het. Gevolglik het die vraag ontstaan of die Wêreldraad self nie ekklesiologiese relevansie en betekenis het nie.

'n Insig wat met hierdie ontwikkelinge na vore getree het, is die bewussyn dat die wedersydse begrip en samewerking waarna gestreef word nie verkry kan word deur'n benadering van onderlinge vergelyking en konfrontasie waarin die een standpunt die ander moet oorwin nie. Hierdie benadering berus op die Westers-modernistiese voorveronderstelling van 'n universeel-geldige rasionaliteitsmodel. Dit word duidelik dat hierdie benadering eerder met ' $n$ konsensussoekende metode vervang moet word, waar die kerk nie as 'n filosofiese skool gesien word nie, maar as 'n pelgrimsvolk waarin verskillende groepe van mekaar leer hoe om die waarheid saam te soek en te onderskei.

In die 1960's het die idee van konsiliariteit na vore getree as 'n meganisme waardeur eenheid en verskeidenheid gelyktydig hanteer kan word (Veenhof 1981). Alhoewel dit duidelik was dat ' $n$ institusionele vormgewing van die wêreldkerk nog nie moontlik was nie, was dit 'n term wat konkrete uitdrukking kon gee aan die strewe daarna. Die Faith and Order-Kommissie druk dit as volg uit (Brinkman 1995):

By conciliarity we mean the coming together of Christians locally, regionally or globally - for common prayer, counsel and decision, in the belief that the Holy Spirit can use such meetings for his own purpose of reconciling, renewing and reforming the Church by guiding it towards the fullness of truth and love. (p. 25)

Aangesien die gedagte van konsiliariteit steeds misverstaan kan word, word hierdie term algaande deur die begrip koinonia vervang om uitdrukking te gee aan die kerklike ideaal wat die Wêreldraad voor oë staan. Omdat hierdie term minder institusionele beperktheid impliseer as wat met die idee van konsiliariteit gepaard gaan, bevat dit die potensiaal om veel meer en ook meer fundamentele dimensies van die ekklesiologie aan die orde te stel (Schwöbel 1996: 11). Alhoewel die term koinonia nie as 'n primêre kategorie in die Nuwe Testamentiese ekklesiologie funksioneer nie, dien dit tog as 'n sintese-begrip waarmee die betekenis van ander basiese beelde vir die kerk, soos volk van God, liggaam van Christus en tempel van die Heilige Gees, met mekaar verbind kan word. Dit dui op die onderlinge verhouding van gelowiges en geloofsgroepe wat tot stand kom vanweë hul gemeenskaplike verbondenheid aan die drie-enige God. Die koinonia van gelowiges en geloofsgroepe is gegee in hul koinonia met God in Christus en deur die Heilige Gees.

Die teologiese diepgang wat die koinonia-begrip aan die ekklesiologie verleen deur die aandag te vestig op die transendente oorsprong en konteks van die kerk, mag nie die oё daarvoor laat sluit dat koinonia in die Nuwe Testament ook dui op die deel van materiële dinge nie. Hier kan as voorbeeld verwys word na Paulus se kollekte vir die gelowiges in Jerusalem. Kerklike gemeenskap het heel duidelik ook ' $n$ morele dimensie.
Namate die wedersydse begrip en verstandhouding tussen kerke oor die wêreld heen langsamerhand gegroei het aan die hand van die motiewe van konsiliariteit en koinonia, het dit duidelik geword dat vordering op die pad van moontlike institusionele eenwording alleenlik sou gebeur indien die fundamentele vrae oor die aard en doel van kerkwees, wat sedert die Torontoverklaring angsvallig in Wêreldraadkringe uit die weg gegaan is, nie langer vermy sou word nie. Daarom het die Faith and Order-Kommissie in 1989 besluit om 'n omvattende studie oor die ekklesiologie aan te pak (Best 1990:219). Na byna 10 jaar se werk is 'n eerste ontwerpdokument in 1998 gepubliseer wat, nadat kommentaar daarop ontvang is, opnuut in 2005 uitgegee is onder die titel The nature and mission of the church. A stage on the way to a common statement (World Council of Churches 2005).

Vir die doeleinde van hierdie artikel is dit belangrik om daarop te let dat die laaste van die vier hoofstukke van hierdie dokument aan die verhouding tussen ekklesiologie en etiek gewy is. Dit is eweneens belangrik om in gedagte te hou dat in hierdie laaste hoofstuk van Nature and mission of the church, wat deur die meer teoreties-ingestelde Faith and Order-Kommissie opgestel is, ook gegewens verwerk is uit die bevindinge van 'n ander deelprojek wat deur die meer prakties-georiënteerde Life and Work-tradisie in die Wêreldraad geïnisieer is. Hierdie insiatief het gelei tot 'n selfstandige deelprojek wat van 1992 tot 1996 juis onder die titel Ecclesiology and Ethics onderneem is (Best \& Robra 1997). Die belangrikste bevindinge van hierdie deelprojek was dat etiek in 'n Christelike konteks gesien moet word as 'n dimensie van die ekklesiologie en dat die Christelike identiteit van gelowiges versterk moet word met die oog op die uitdra van en oriëntasie in Christelike waardes (Forrester 1997:76-95).

Om vas te stel hoe hierdie insigte by die laaste hoofstuk van Nature and Mission of the Church inpas, moet ons kortliks let op die kerninhoud van hierdie laaste hoofstuk. Die gesigspunt wat vooropstaan, is dat die kerk nie in die eerste instansie in sy eie belang bestaan nie, maar met die doel om as instrument in die hand van God te dien tot transformasie van die wêreld. Hiermee word bedoel dat diens (diakonia) tot die wese van die kerk behoort. Hierdie diensbaarheid impliseer dat wanneer Christelike gemeenskappe gekonfronteer word met rampe, soos hongersnood of die Vigs-pandemie, hulle nie afsydig mag staan nie. Waar die vrede bedreig word deur destruktiewe magte, soos ekonomiese onreg, rassisme of religieuse fanatisme, is Christene geroep om by te dra tot die verwydering van die oorsake van die stryd. Verder dring hul geloof hulle ook om deel te neem aan die totstandkoming van 'n regverdige sosiale en politieke orde waarin die goedere van hierdie wêreld op 'n meer billike wyse deur almal gedeel kan word, absolute armoede opgehef kan word en die waardigheid van mense beter beskerm kan word.

Dat dissipelskap morele toewyding impliseer, hang daarmee saam dat Christene in ' $n$ ruimte van genade en vergifnis leef. Dit is op hierdie basis van regverdiging uit genade en deur geloof alleen dat gemeenskaplike morele optrede beskou kan word as intrinsiek deel van die lewe van die kerk. 
Die Christelike etiek, met sy wortels in die openbaring van God, het betrekking op sowel die kerk as die wêreld. Die kerk kan haarself nie uit die groot morele vraagstukke van die moderne wêreld isoleer nie. Die kerk moet dus met die aanhangers van ander godsdienste en met mense van goeie wil saamwerk om die waardes van die koninkryk van God in die hantering van dringende etiese vrae in die persoonlike en sosiale sfeer te bevorder. Die prediking van die koninkryk moet in die samelewing werk soos 'n suurdeeg wat die hele deeg laat rys. Daar moet veral met politieke en ekonomiese maghebbers saamgewerk word om koninkrykswaardes tot hul reg te laat kom en om teenstrydige beleid en inisiatiewe teen te gaan. Langs hierdie weg kan Christene in die tradisie staan van die profete wat aan Gods oordeel teen alle onreg uitdrukking gegee het.

In 'n komplekse moderne wêreld is dit te verwagte dat situasies waar kerke oor morele sake sal verskil, sal ontwikkel. In sulke omstandighede moet dialoog volgehou word ten einde vas te stel of die verskille uit die weg geruim kan word en of hulle werklik van kerkskeidende aard is.

Dit is belangrik dat geloofsgemeenskappe in hul etiese besinning en beslissings aan mekaar verantwoordbaar sal bly. Dit is die wyse waarop die koinonia wat tussen hulle bestaan uitdrukking kan vind.

\section{Morele transformasie en oriëntasie}

Wanneer 'n mens kennis neem van die wyse waarop die tema 'ekklesiologie en etiek' in die kringe van die Wêreldraad van Kerke ter sprake gebring is, is dit begryplik dat wanneer De Villiers in die 1980's by die breë ekumeniese beweging aansluiting vind, hy die NG Kerk moes wys op die elemente van ' $n$ dreigende morele deformasie wat besig was om in haar midde te ontwikkel. As 'n mens egter verder let op die wyse waarop De Villiers vervolgens die NG Kerk tot 'n bydrae in verband met morele transformasie van en morele oriëntasie in die Suid-Afrikaanse samelewing aanspoor, blyk dit dat sy benadering in hierdie verband eweneens in ooreenstemming is met tendense wat in die breë ekumeniese beweging voorkom.

'n Belangrike bydrae wat De Villiers gelewer het ten opsigte van morele transformasie, is die beklemtoning dat die kerk 'n onontbeerlike vredestaak in 'n situasie van ernstige konflik het. In sinodale dokumente en ander publikasies het hy beklemtoon dat vrede, volgens Christelike oortuiging, meer is as die afwesigheid van oorlog. Vrede is die regte orde in die heelal. Dis die orde soos God dit bedoel het - die orde waarin God, mens en natuur in volkome harmonie met mekaar bestaan. Dit is die vrede, sê De Villiers, wat die Bybel in gedagte het wanneer gelowiges opgeroep word om vredemakers te wees. So 'n vrede bevoordeel nie slegs bepaalde groepe mense nie, maar is daar tot voordeel van almal (De Villiers 1988:9-22).

In 'n situasie van intense konflik is dit nie maklik om 'n bemiddelingsrol te speel nie. Dit het moed van De Villiers geverg om in die 1980's te beklemtoon dat gelowiges steeds versoening met hul vyande moet nastreef en selfs bereid moet wees om eerder onreg te ly as om ander kwaad aan te doen. Waar daar van gewapende stryd sprake is, moet gelowiges poog om voorrang te verleen aan die nie-gewelddadige metodes om vrede te bevorder. In die destydse Suid-Afrika het De Villiers beklemtoon dat Christene die strydende partye moet probeer oortuig dat die oorwinning oor vyandskap 'n veel beter weg tot die verwesenliking van die ideaal van 'n gemeenskaplike vrede is as die oorwinning oor die vyand.

Vrede is op die lang duur slegs moontlik as dit tot voordeel van al die inwoners van die land is. Een van die dringendste voorwaardes vir vrede, 20 jaar gelede en nogsteeds, is die noodsaak om die dramatiese armoedevraagstuk en die probleem van die groot ekonomiese ongelykheid effektief te hanteer. De Villiers het telkens beklemtoon dat die kerk, en met name die NG Kerk, 'n belangrike rol hierin kan speel deur enersyds sy lidmate daarvoor te motiveer en andersyds op allerlei praktiese maniere daarby betrokke te raak (De Villiers 2000:440-455).

De Villiers het egter nie net die kerk opgeroep om 'n morele transformasierol te vervul nie, maar ook om betrokke te raak in die bied van morele oriëntasie. Dit is naamlik bekend dat samelewings wat ingrypende veranderinge deurmaak in ' $n$ morele vakuum teregkom. Dit is begryplik dat dit sedert die politieke herskikking ook in Suid-Afrika sou gebeur. De Villiers het die agtergrond van die morele krisis in Suid-Afrika in verskillende publikasies ontleed en gewys op veroorsakende faktore, soos die geweldskultuur en morele afstomping wat met militêre konflik gepaard gaan, ekonomiese wanbalanse in die samelewing en die deurbraak van die sekularisasieproses in Suid-Afrika nadat die isolasie wat deur die vorige politieke bedeling teweeggebring was, beëindig is (De Villiers 1999, 2000).

'n Belangrike aksent in De Villiers se werk is dat hy eweneens in verskillende publikasies klem gelê het op die bydrae wat ook die Afrikaanse kerke kan lewer tot die morele genesing van die samelewing. In hierdie verband wys hy in die eerste plek daarop dat dit van belang is dat die kerke, sover dit in hul vermoë is, meewerk om die omstandighede wat tot die morele krisis aanleiding gee, uit die weg te ruim. Verder is dit nodig dat hulle op die gebruiklik kerklike wyse (deur erediens, sakramentsbediening en kategese) tot die morele vorming van hul lidmate bydra. Dit is veral belangrik dat lidmate begelei word om die vaardigheid van selfstandige, morele besluitneming te ontwikkel en dat evangeliese waardes in gesinne aan jong mense oorgedra word. De Villiers het in verskillende verbande beklemtoon dat die onkritiese oorname van die materialistiese waardes van die vryemarkekonomie teengegaan moet word.

Van tyd tot tyd sluit De Villiers by kollega-etici aan met die suggestie dat die morele oriëntasie wat die kerk bied, beskryf kan word aan die hand van Christus se drie ampte. So dui 
hy, byvoorbeeld, daarop dat die erediens by geleentheid so ingeklee behoort te word dat lidmate wat traumatiese ervaringe in die arbeidswêreld beleef, die vertroostende en genesende genade van God kan ervaar. Terselftertyd moet hulle egter ook toegerus word om as konings te oorwin oor die sonde en die negatiwiteit in die werksplek, en as profete by te dra tot die transformasie van immorele arbeidspraktyke (De Villiers 2004:915-917).

\section{Slotsom}

Wanneer ons dit alles op ons laat inwerk, kan die konklusie nie anders wees nie as dat Etienne De Villiers, in lyn met tendense in die breë ekumeniese wêreld, 'n besondere bydrae gelewer het tot die verruiming van die moraliteitsen kerkbegrip in die Suid-Afrikaanse konteks, asook tot die belangrike verantwoordelikheid om die komplekse verband tussen hierdie twee begrippe te verhelder. Alhoewel hy nog nie 'n omvattende en sistematiese ekklesiologie uitgewerk het nie, toon sy werk dat so 'n ekklesiologie sterk aansluiting sal vind by tendense wat in die breë ekumeniese beweging aangetref word.

\section{Acknowledgements Competing interests}

Die outeur verklaar hiermee dat hy geen finansiële of persoonlike verbintenis het met enige party wat hom nadelig kon beinvloed in die skryf van hierdie artikel.

\section{Literatuurverwysings}

Best, T.F., 1990, Faith and Order 1985-1989: The commission meeting at Budapest, WCC, Geneva.

Best, T.F. \& Robra, M., 1997, Ecclesiology and Ethics. Ecumenical ethical engagement moral formation and the nature of the church, WCC, Geneva.

Brinkman, M.E., 1995, Progress in unity?, Peeters, Louvain.

De Villiers, D.E., 1986, 'Kritiek uit die ekumene', in J. Kinghorn (red.), Die NG Kerk en apartheid, pp. 144-164, Macmillan, Johannesburg.

De Villiers, D.E., 1988, 'Die evangelie van vrede en vrede in Suid-Afrika', in C.J. Wethmar \& C.J.A. Vos (reds.), 'n Woord op sy tyd (F.S.J.A. Heyns), pp. 9-22, NG Kerkboekhandel, Pretoria.

De Villiers, D.E., 1989, 'Tussen simpatie en veroordeling', in P.F. Theron \& J. Kinghorn (reds.), Koninkryk, kerk en kosmos (F.S.W.D Jonker), pp. 144-163, Pro Christo (reds.), Koninkryk, kerk en
Publikasies, Bloemfontein.

De Villiers, D.E., 1995, 'Die Nederduitse Gereformeerde Kerk en die nuwe situasie in die samelewing', Ned Geref Teologiese Tydskrif 36(4), 558-569.

De Villiers, D.E., 1999, 'Die NG Kerk en die oorgang na 'n nuwe Suid-Afrika', Verbum et Ecclesia 20(1), 15-38.

De Villiers, D.E., 2000, 'Die morele genesing van die Suid-Afrikaanse samelewing: die bydrae van die Afrikaanse kerke', Hervormde Teologiese Studies 56(2-3), 440-455.

De Villiers, D.E., 2004, 'Durf ons nog preek dat werk 'n roeping van God is?', HTS Teologiese Studies 60(3), 901-918.

De Villiers, D.E., 2008, 'Kan die NG Kerk nog ' $n$ konstruktiewe rol in die Suid-Afrikaanse samelewing speel?', Verbum et Ecclesia 29(2), 368-386.

De Villiers, D.E., 2010, 'The public role of churches in present democratic South Africa', in J.D. Gort, H. Jansen \& W. Stoker (eds.), Crossroad discourses between Christianity and culture, pp. 197-214, Rodopi, Amsterdam.

Forrester, D., 1997, The true church and morality. Reflections on ecclesiology and ethics, WCC, Geneva.

Schwöbel, C., 1996, 'Kirche als communio', in W. Härle \& R. Preul (eds.), Marburger Jahrbuch theologie 8, 11-46.

Veenhof, J., 1981, 'Pluraliteit en conciliariteit', in J.M. Vlijm (red.), Geloofsmanieren. Studies over pluraliteit in de kerk, pp. 168-197, Kok, Kampen.

Wethmar, C.J., 2010, 'Recent ecclesiological developments in the World Council of Churches: continuity or discontinuity?', in J.D. Gort, H. Jansen \& W. Stoke (eds.), Crossroad discourses between Christianity and culture, pp. 505-523, Rodopi, Amsterdam.

Wiles, M., 2001, A shared search. Doing theology in conversation with one's friends, SCM, London.

World Council of Churches, 2005, The nature and mission of the church: A stage on the way to a common statement, WCC, Geneva. 